\title{
Methods of sputum processing for cell counts, immunocytochemistry and in situ hybridisation
}

\author{
Leader of the Working Group: A. Efthimiadis*, A. Spanevello\# \\ Members of the Working Group: Q. Hamid", M.M. Kelly ${ }^{+}$, M. Linden ${ }^{\S}$, R. Louis ${ }^{f}$, \\ M.M.M. Pizzichini**, E. Pizzichini**, C. Ronchi\#\# ${ }^{\#}$, F. Van Overveld ${ }^{\text {đq }}$, R. Djukanović ${ }^{+}$
}

Since the first attempts to use standardised methods for sampling induced airways sputum, two methods for processing the expectorate have evolved. The first involves selecting all viscid or denser portions from the expectorated sample with the aid of an inverted microscope $[1,2]$. This method has been extensively evaluated and reported in detail [2-4]. The second approach involves processing the entire expectorate, comprising sputum plus variable amounts of saliva [5]. Recent modifications to this method include collecting saliva and sputum separately in order to reduce salivary contamination [6-8]. Both methods have advantages and disadvantages.

The advantages of using selected sputum are: squamous cell contamination is $<5 \%$, making cell counting easier and quicker to perform, the total cell count (TCC) can be expressed per gram of lower airway secretions, and concentrations of chemicals in the fluid phase are unaffected by the confounding influence of saliva, and can be accurately corrected for dilution. The disadvantage is that selection takes a few minutes longer to perform and requires an inverted microscope. The advantage of using the entire expectorate is that the technique is quicker to perform, but there are some disadvantages that require consideration. The expectorate contains a variable mixture of sputum plus saliva which may dilute the sputum and confound its analysis. The reproducibility of cell counts has been reported to be lower if squamous cell contamination represents $>20 \%$ of all recovered cells [4]. There is conflicting data as to whether or not differential cell counts (DCCs) differ between the two methods. One study reported a higher percentage of eosinophils in sputum processed by the selection method compared to the entire expectorate [9] but this has not been confirmed in other studies $[2,6,10]$. Although, both the selected sputum and the entire expectorate methods have the same ability to distinguish asthmatics or bronchitics from healthy subjects, they are not interchangeable, and, once a technique has been adopted for a given study, it should always be applied.

When evaluating the most appropriate method for processing sputum for cellular analysis, a number of issues need to be considered: 1) sputum sample homogenisation; 2) duration and temperature of homogenisation; 3) volume and concentration of added mucolytic; 4) sample filtration; 5) TCC and viability; 6) centrifugation and storage of supernatant; 7) cytospin centrifugation, staining and counting; 8) metachromatic cell staining and counting; 9) slide reading quality control; 10) immunocytochemical staining; and 11) in situ hybridisation. Figure 1 is representative of the two methods of processing to yield accurate cell counts.

\section{Sputum sample homogenisation}

It is recommended that sputum be processed as soon as possible or within $2 \mathrm{~h}$ in order to ensure optimum cell counting and staining $[2,5]$. Complete homogenisation is important and can be achieved by the use of dithiothreitol (DTT) and dithioerythritol to break the disulphide bonds in mucin molecules, allowing cells to be released [11]. Cells that are incompletely released from mucus tend to stain darkly, making correct identification difficult. DTT (0.1\%), commonly known as $10 \%$ sputalysin solution, has been shown to be more effective at dispersing cells than phosphate-buffered saline (PBS), and has no adverse affects on cell counts. Although some fluid-phase

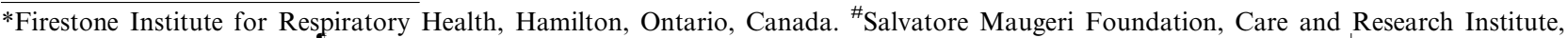
Cassano delle Murge, Italy. "Meakins-Christie Laboratories, McGill University, St Urbain, Montreal, Quebec, Canada. ${ }^{+}$Dept of Pathology and Molecular Medicine, McMaster University, Hamilton, Ontario, Canada. ${ }^{\circledR}$ Dept of Respiratory Medicine, Lund University Hospital, Lund, Sweden. ${ }^{f}$ Dept of Pneumology, Hospital of Sart Tilman, Liege, Belgium. ${ }^{* *}$ Asthma Research Centre, Dept of Internal Medicine, Federal University of Santa Catarina, Florianópolis, Santa Catarina, Brazil. \#\# Dept of Internal Medicine, Section of Immunoallergology and Respiratory Disease, University of Florence, Florence, Italy. "Dept of Respiratory Medicine, University of Antwerp, Antwerp, Belgium.

${ }^{+1}$ Division of Infection, Inflammation and Repair, Respiratory Cell \& Molecular Biology, Southampton General Hospital, Southampton, UK.

Correspondence: A. Efthimiadis, Firestone Institute for Respiratory Health, 50 Charlton Avenue East, Hamilton, Ontario, L8N 4A6, Canada. Fax: 1905 5216158. E-mail: efthima@mcmaster.ca
}

Received: April 4 2002; Accepted: April 162002 
a)

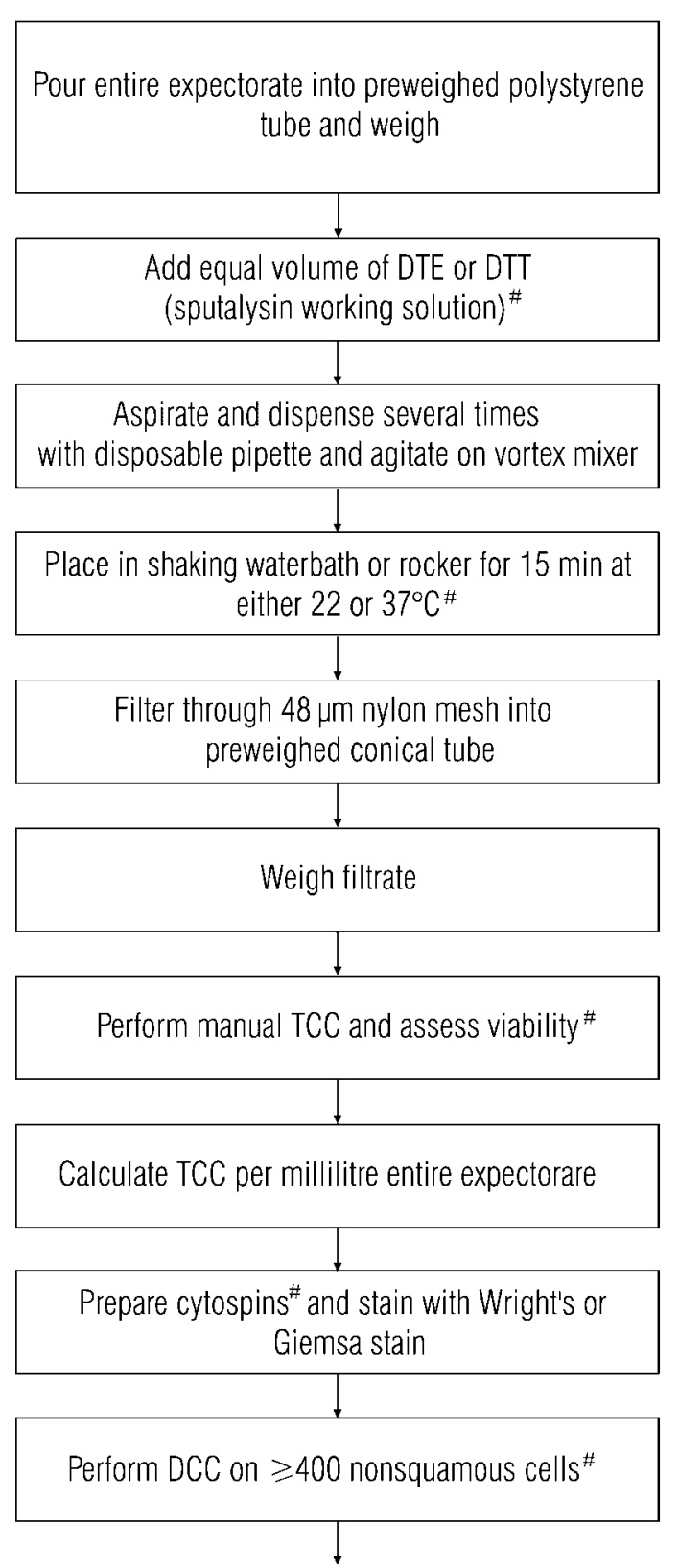

b)

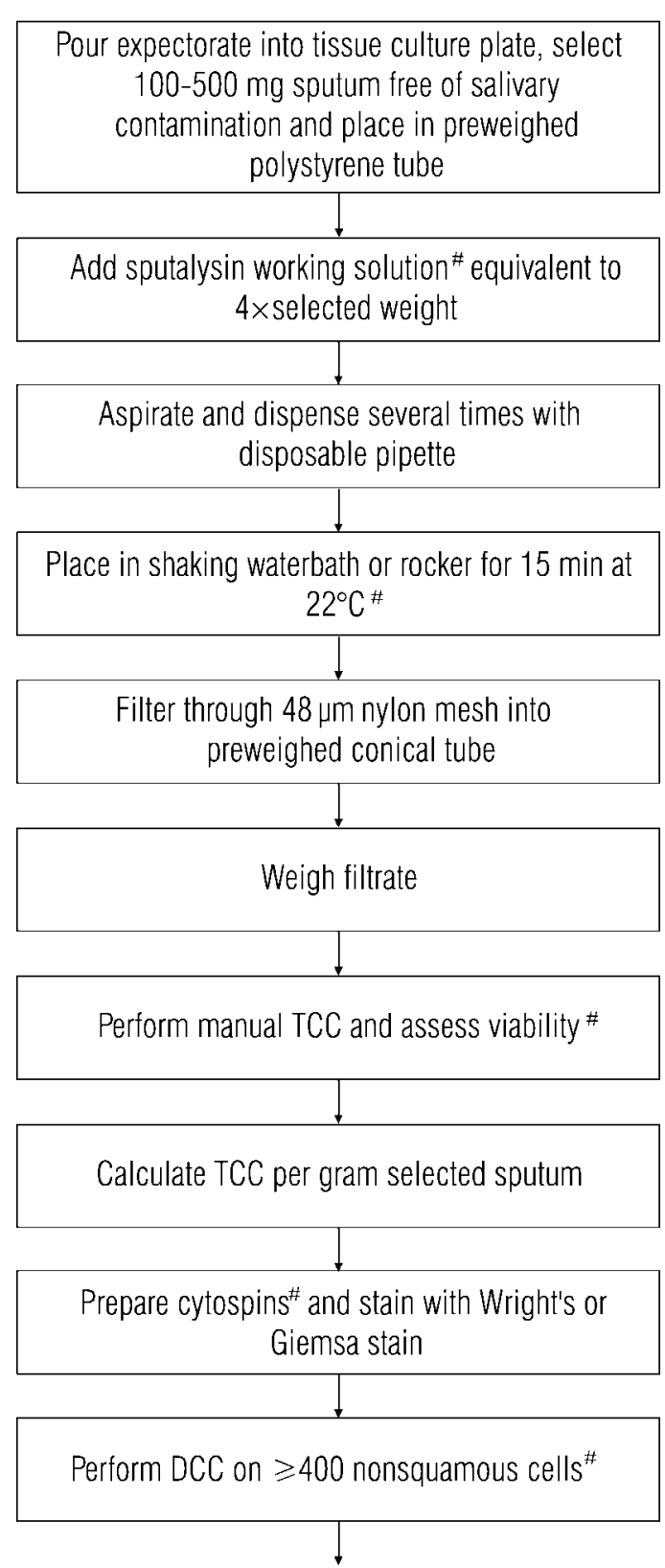

Fig. 1.-Sputum processing method for: a) entire sputum; and b) selected sputum. DTE: dithioerythritol; DTT: dithiothreitol; TCC: total cell count; DCC: differential cell count. ${ }^{\#}$ : see appendix.

indices such as interleukin-5 and -8 and fibrinogen concentrations remain unaffected, levels of eosinophil cationic protein and immunoglobulin $\mathrm{A}$ are increased when DTT or dithioerythritol are used $[12,13]$. The effect of the dispersing agent in use should be tested for each marker of interest (see article entitled "Analysis of fluid-phase mediators" [14] for more detail).

\section{Duration and temperature of homogenisation}

The duration and temperature of homogenisation vary between investigators, time ranging $10-30 \mathrm{~min}$ and temperature $4-37^{\circ} \mathrm{C}$. It has been demonstrated that different exposure times to DTT at room temperature have no effect on the DCC [15]. A recent study comparing the effect of processing at room temperature and $37^{\circ} \mathrm{C}$ on the cellular and fluid composition of sputum has shown no significant differences [12]. This indicates that processing at $37^{\circ} \mathrm{C}$, which requires a water bath, may be of no additional benefit. Homogenisation is possible by using either a shaking water bath at $37^{\circ} \mathrm{C}$ (and removing the sample periodically for brief aspiration) or a tube rocker at $22^{\circ} \mathrm{C}[5,9,12]$. Few researchers advocate the use of aspiration and expulsion of sputum with a plastic transfer pipette as this has been proven to decrease cell yield due to incomplete homogenisation $[15,16]$. 


\section{Volume and concentration of added mucolytic}

The volume of mucolytic used during processing of entire expectorate, although fixed at $1: 1$, is variable in relation to the ratio of sputum to saliva, which is unknown $[5,6]$. The volume used in the selected sputum method is fixed.

\section{Sample filtration}

Filtration through a $48-\mu \mathrm{m}$ nylon mesh is commonly used to remove mucus and debris, and is strongly recommended. A single filtration step results in a slight reduction in the TCC. However, slide quality is improved and the DCC remains unchanged $[3,17]$. To date, little is known about the effect of multiple mesh filtrations on the TCC and DCC and this needs further investigation.

\section{Total cell count and viability}

The TCC is performed manually using a haemocytometer, and cell viability is determined by the trypan blue exclusion method by most investigators $[5,18]$. One important difference is that some perform the TCC before centrifugation and others after centrifugation. A reduction after centrifugation has been shown by RERECICH et al. [19] and more recently by EFTHIMIADIS et al. [20], who compared sputum cell counts and found a 38\% reduction in cell yield after centrifugation. It is, therefore, recommended that the TCC be performed before centrifugation in order to facilitate standardisation of this measurement and to allow meaningful comparisons of counts between centres and studies. Automated methods for determining TCC and DCC have been investigated and found unreliable $[15,16]$. Automation is an important consideration for the evolution of the method, but is not recommended at present.

\section{Centrifugation and storage of supernatant}

Centrifugation is necessary to separate sputum cells from the fluid phase. The centrifugal force used to date has ranged $300-1,500 \times g$ and the duration of centrifugation 5-10 min. This appears adequate for the purpose of separating cells from the supernatant $[5,12,18]$; however, the effect on fluid-phase measurements needs further investigation. The storage temperature used has ranged $-20-70^{\circ} \mathrm{C}$ [18]. Further investigation is required to determine the optimum storage temperature, which may vary for the different fluid phase measurements (see article entitled "Analysis of fluid-phase mediators" [14] for more details).

\section{Cytospin centrifugation, staining and counts}

Preparation of cytospins with an optimum number of cells $\left(40-60 \times 10^{3}\right.$ cells) provides a more accurate estimate of cell distribution than smears [15, 18].
Cytocentrifugation speeds range $10-51 \times g$ (using a cytocentrifuge obtained from Shandon Southern Instruments, Sewickley, PA, USA), with the most common conditions being $22 \times g$ for 6 min $[15,18]$. Although all are within the limits for minimal cell distortion, there is a risk of losing lymphocytes at lower speeds $[21,22]$. This should be taken into consideration in investigations of sputum lymphocytes.

Cytospin staining for DCCs can be achieved using either Wright's or Giemsa stain. Care should be taken to ensure that buffers are at the appropriate $\mathrm{pH}$ (7.1-7.2) and that stains are prepared according to manufacturers' recommendations for optimum results. This allows accurate characterisation of cells on the basis of their staining and morphology. The DCC is determined by counting a minimum of 400 nonsquamous cells and is reported as the relative numbers of eosinophils, neutrophils, macrophages, lymphocytes and bronchial epithelial cells, expressed as a percentage of total nonsquamous cells. The percentage of squamous cells should always be reported separately.

\section{Metachromatic cell staining and counts}

Historically, metachromatic staining, which identifies both basophils and mast cells, has been performed by means of toluidine blue staining [5, 9, 15, 18]. Although meaningful results have been obtained, one of the difficulties with this method is obtaining optimum staining intensity. Cells are often quite pale, which makes cell identification and enumeration difficult. This phenomenon appears to be specimendependent and can be resolved by increasing the staining time from 10 to $60 \mathrm{~min}$. A recent study by Gavreau et al. [23] identified the possibility of discriminating between basophils and mast cells using immunocytochemical techniques. Basophils can be identified with the 2D7 antibody, which immunolocalises specifially to human basophil secretory granules. Mast cells can, conversely, be identified with an alkaline phosphatase-conjugated antitryptase antibody that binds specifically to tryptase, a protease found almost exclusively in mast cells. This would be the method of choice in studies in which differentiation between basophils and mast cells is relevant.

\section{Slide reading quality control}

Every laboratory requires an adequate quality control programme as an intergral part of standard operating procedure protocols. This is particularly important when slide readings are used to monitor patient medication. Incorrect results can lead to incorrect diagnosis, treatment and research direction. First and foremost, it is mandatory that staff are both qualified and fully trained to avoid legal implications should problems arise. Monthly quality control should include internal slide reading as well as equipment calibration; unless a certain standard of performance is realised, "normal values" have no significance. 


\section{Immunocytochemical staining}

The sputum cell suspension is centrifuged at $300 \times g$ for $10 \mathrm{~min}$, and the pellet resuspended in PBS. Cytospins are prepared on polylysine-coated slides to ensure minimum loss of cells during multiple washing steps. They are dried in air for $10 \mathrm{~min}$ and fixed appropriately. SHI et al. [24] have shown that some antigens are cross-linked by paraformaldehyde and require antigen-retrieval before they can be recognised by the relevant antibody. Thus the method of fixation is critical and needs to be determined as being optimal for the antigen in question. Some commonly used fixatives are 2 or $4 \%$ paraformaldehyde, formalin, acetone/methanol (60/40) and periodate/lysine/paraformaldehyde. The latter is a fixative for glycoprotein surface staining, but may also be used for cytokines [25]. After fixation, cytospins should be wrapped in foil and stored at $-20^{\circ} \mathrm{C}$ pending staining. Immunocytochemical staining can be performed using various protocols, including avidin/biotin complex, peroxidase/antiperoxidase and alkaline phosphatase/antialkaline phosphatase techniques [23, 26, 27]. The alkaline phosphatase/antialkaline phosphatase method is recommended and involves application of monoclonal antibodies on fixed slides at appropriate concentrations and incubation overnight at $4{ }^{\circ} \mathrm{C}$. Secondary antibodies are then applied and the antibody/antigen complex is visualised using the alkaline phosphatase-linked substrate, with either fast red or fast blue counterstains. Negative controls must always be included to facilitate exclusion of possible false positives due to nonspecific staining. Peroxidase staining methods are not reccommended for sputum.

\section{In situ hybridisation}

Collection of sputum for in situ hybridisation is as described for immunostaining. In addition, the use of sterile containers and solutions is crucial in order to avoid ribonuclease contamination. Cytospins should be prepared on polylysine-coated slides to reduce cell loss. Fixation is conducted in $4 \%$ paraformaldehyde for $30 \mathrm{~min}$ followed by two washes in PBS for $5 \mathrm{~min}$. Following fixation, preparations are dried at $37^{\circ} \mathrm{C}$ and used immediately or stored at $-80^{\circ} \mathrm{C}$ for later processing. For detection of messenger ribonucleic acid (RNA), a sterile environment is essential. Preparations should be handled with gloves and all materials and solutions should be sterile. Although both radioactive and nonradioactive deoxyribonucleic acid (DNA) or RNA probes can be used, radiolabelled complementary RNA is recommended to ensure high specificity and sensitivity. These probes are usually generated from complementary DNA and do not exceed 200-300 base pairs. Hybridisation can be performed according to standard protocols [28]. Following hybridisation, slides should be washed under high-stringency conditions and the hybridisation signal visualised using autoradiography. As for immunocytochemistry, negative controls should always be used, including the use of sense probes and ribonuclease pretreatment.

\section{Key points}

It is important to: 1) ensure complete homogenisation of sputum; 2) filter the sputum to remove excess mucus and debris; 3 ) perform a manual TCC prior to centrifugation; 4) count the entire volume of the counting chamber; 5) prepare cytopsins with an optimum number of cells; 6) ensure that buffers and stains are optimised; 7) perform a 400-nonsquamous cell DCC; 8) report the squamous cells separately; 9) include positive and negative controls with special stains; 10) implement a regular quality control system; and 11) use standard operating procedures.

\section{Outstanding questions}

Research questions that still need addressing include the following. 1) What is the lowest acceptable cell viability for reliable cell counts? 2) What is the effect of time lapse to processing sputum on cells and fluid-phase measurements? 3) What is the influence of rocking versus standing on the bench on cells and fluid-phase measurements? 4) What is the effect of centrifugation rates on cell morphology and fluid-phase markers? 5) What is the effect of multiple mesh filtration on cell counts and fluid-phase measurements?

\section{Appendix: sputum processing methods}

\section{Sputalysin working solution}

Mix $0.1 \mathrm{~mL} 10 \%$ sputalysin and $0.9 \mathrm{~mL}$ distilled water. Prepare fresh daily.

\section{Processing temperature}

Processing at $22^{\circ} \mathrm{C}$ (room temperature) is adequate for cell counts. To date, this temperature has been used for the selected sputum method. Processing at $37^{\circ} \mathrm{C}$ does not provide any additional benefit. The effect of temperature on subsequent fluid-phase measurements needs to be considered in advance.

\section{Total cell count and viability}

Mix $10 \mu \mathrm{L}$ trypan blue and $10 \mu \mathrm{L}$ sputum cell suspension. Flood Neubauer haemocytometer counting chamber. Count the entire area $\left(9 \mathrm{~mm}^{2}\right)$. Report cell viability as a percentage. A cell viability of $<40 \%$ may affect the DCC.

\section{Cytospin preparation}

Adjust cell concentration to $1.0 \times 10^{6}$ cells $\cdot \mathrm{mL}^{-1}$. Add $40-65 \mu \mathrm{L}$ sample (or $450-650 \times 10^{3}$ cells) to each cytospin. 


\section{Differential cell counting}

Stain with Wright's or Giemsa stain. Count 400 nonsquamous cells. Report proportions of neutrophils, eosinophils, macrophages, lymphocytes and bronchial epithelial cells relative to total nonsquamous cell count. Report proportion of squamous cell contamination separately.

\section{References}

1. Pin I, Gibson PG, Kolendowicz R, et al. Use of induced sputum cell counts to investigate airway inflammation in asthma. Thorax 1992; 47: 25-29.

2. Pizzichini E, Pizzichini MM, Efthimiadis A, Hargreave FE, Dolovich J. Measurement of inflammatory indices in induced sputum: effects of selection of sputum to minimize salivary contamination. Eur Respir J 1996; 9: 1174-1180.

3. Efthimiadis A, Popov T, Kolendowicz R, Dolovich J, Hargreave FE. Increasing the yield of sputum cells for examination. Am J Respir Crit Care Med 1994; 149: A949.

4. Efthimiadis A, Pizzichini MMM, Kolendowicz R, Weston S, Dolovich J, Hargreave FE. The influence of cell viability and squamous epithelial cell contamination on the reliability of sputum differential cell counts. Am J Respir Crit Care Med 1995; 151: A384.

5. Fahy JV, Liu J, Wong H, Boushey HA. Cellular and biochemical analysis of induced sputum from asthmatic and from healthy subjects. Am Rev Respir Dis 1993; 147: 1126-1131.

6. Gershman NH, Wong HH, Liu JT, Mahlmeister MJ, Fahy JV. Comparison of two methods of collecting induced sputum in asthmatic subjects. Eur Respir $J$ 1996; 9: 2448-2453.

7. Keatings VM, Collins PD, Scott DM, Barnes PJ. Differences in interleukin-8 and tumor necrosis factor$\alpha$ in induced sputum from patients with chronic obstructive pulmonary disease or asthma. Am J Respir Crit Care Med 1996; 153: 530-534.

8. Louis R, Shute J, Biagi S, et al. Cell infiltration, ICAM-1 expression, and eosinophil chemotactic activity in asthmatic sputum. Am J Respir Crit Care Med 1997; 155: 466-472.

9. Spanevello A, Beghe B, Bianchi A, et al. Comparison of two methods of processing induced sputum: selected versus entire sputum. Am J Respir Crit Care Med 1998; 157: 665-668.

10. Taylor DA, Kanabar V, Cook RM, O'Connor BJ. Selection of sputum plugs from induced sputum of asthmatic patients does not improve cellular analysis. Am J Respir Crit Care Med 1997; 155: A822.

11. Cleland WW. Dithiothreitol, a new protective reagent for SH groups. Biochemistry 1964; 3: 480-482.

12. Louis R, Shute J, Goldring K, et al. The effect of processing on inflammatory markers in induced sputum. Eur Respir J 1999; 13: 660-667.

13. Efthimiadis A, Pizzichini MM, Pizzichini E, Dolovich J, Hargreave FE. Induced sputum cell and fluid-phase indices of inflammation: comparison of treatment with dithiothreitol vs phosphate-buffered saline. Eur Respir $J$ 1997; 10: 1336-1340.

14. Kelly MM, Keatings V, Leigh R, et al. Analysis of fluid-phase mediators. Eur Respir J 2002; 20: Suppl. 37, $24 \mathrm{~s}-40 \mathrm{~s}$.

15. Popov T, Gottschalk R, Kolendowicz R, Dolovich J, Powers P, Hargreave FE. The evaluation of a cell dispersion method of sputum examination. Clin Exp Allergy 1994; 24: 778-783.

16. Hansel TT, Braunstein JB, Walker C, et al. Sputum eosinophils from asthmatics express ICAM-1 and HLA-DR. Clin Exp Immunol 1991; 86: 271-277.

17. Efthimiadis A, Weston S, Carruthers S, Hussack P, Hargreave FE. Induced sputum: effect of filtration on the total and differential cell counts. Am J Respir Crit Care Med 2000; 161: A853.

18. Pizzichini E, Pizzichini MM, Efthimiadis A, et al. Indices of airway inflammation in induced sputum: reproducibility and validity of cell and fluid-phase measurements. Am J Respir Crit Care Med 1996; 154: 308-317.

19. Rerecich TJ, Gauvreau GM, Kelly MM, Hargreave FE, O'Byrne PM. Optimization of sputum fluid phase measurements. Am J Respir Crit Care Med 1999; 159: A849.

20. Efthimiadis A, Hussack P, Weston S, Carruthers S, Hargreave FE. Induced sputum: effect of centrifugation on the total and differential cell counts. Eur Respir J 2000; 16: Suppl. 31, 251s.

21. Fleury-Feith J, Escudier E, Pocholle MJ, Carre C, Bernaudin JF. The effects of cytocentrifugation on differential cell counts in samples obtained by bronchoalveolar lavage. Acta Cytol 1987; 31: 606-610.

22. Mordelet-Dambrine M, Arnoux A, Stanislas-Leguern G, Sandron D, Chretien J, Huchon G. Processing of lung lavage fluid causes variability in bronchoalveolar cell count. Am Rev Respir Dis 1984; 130: 305-306.

23. Gauvreau GM, Lee JM, Watson RM, Irani AM, Schwartz LB, O'Byrne PM. Increased numbers of both airway basophils and mast cells in sputum after allergen inhalation challenge of atopic asthmatics. $\mathrm{Am}$ J Respir Crit Care Med 2000; 161: 1473-1478.

24. Shi SR, Cote RJ, Taylor CR. Antigen retrieval immunohistochemistry: past, present, and future. J Histochem Cytochem 1997; 45: 327-343.

25. McLean IW, Nakane PK. Periodate-lysineparaformaldehyde fixative. A new fixation for immunoelectron microscopy. J Histochem Cytochem 1974; 22: 1077-1083.

26. Brandtzaeg P. The increasing power of immunohistochemistry and immunocytochemistry. $J$ Immunol Methods 1998; 216: 49-67.

27. Frew AJ, Kay AB. The relationship between infiltrating CD4+ lymphocytes, activated eosinophils, and the magnitude of the allergen-induced late phase cutaneous reaction in man. J Immunol 1988; 141: 41584164.

28. Hamid Q, Wharton J, Terenghi G, et al. Localization of atrial natriuretic peptide mRNA and immunoreactivity in the rat heart and human atrial appendage. Proc Natl Acad Sci USA 1987; 84: 6760-6764. 